\title{
DISMISSAL FOR FAILURE TO ATTEND A PRETRIAL CONFERENCE AND THE USE OF SANCTIONS AT PREPARATORY STAGES OF LITIGATION*
}

RuLE 16 of the Federal Rules of Civil Procedure authorizes a court to direct the attorneys of parties to appear at a pre-trial conference. ${ }^{1}$ Although setting out the objectives of the pre-trial conference and some of the procedures relating to its conduct, the Rule does not prescribe sanctions for noncompliance with court orders issued pursuant to its provisions. Thus it gives a court no direction for treating a failure by a party's attorney to appear as ordered at a pre-trial conference. The recent Supreme Court decision in Link v. Wabash R.R., ${ }^{2}$ however, affirming a district court's sua sponte dismissal ${ }^{3}$ of a plaintiff's cause of action for his attorney's failure to attend the conference, indicates that courts may take an antipathetic view of such failures. This view not only stands in marked contrast with the response of the courts to noncompliance by a party with orders issued at another stage of the pre-trial process, discovery, but also seems inappropriate where a party is not responsible for his attorney's nonappearance.

*Link v. Wabash R.R., 370 U.S. 626 (1962).

1. FED. R. CIv. P. 16: Pre-Trial Procedure; Formulating Issues

In any action, the court may in its discretion direct the attorncys for the parties to appear before it for a conference to consider

(1) The simplification of the issues;

(2) The necessity or desirability of amendments to the pleadings;

(3) The possibility of obtaining admissions of fact and of documents which will avoid unnecessary proof;

(4) The limitation of the number of expert witnesses;

(5) The advisability of a preliminary reference of issues to a master for findings to be used as evidence when the trial is to be by jury;

(6) Such other matters as may aid in the disposition of the action.

The court shall make an order which recites the action taken at the conference, the amendments allowed to the pleadings, and the agrecments made by the parties as to any of the matters considered, and which limits the issues for trial to those not disposed of by admissions or agreements of counsel; and such order when entered controls the subsequent course of the action, unless modified at the trial to prevent manifest injustice. The court in its discretion may establish by rule a pre-trial calendar on which actions may be placed for consideration as above provided and mas either confine the calendar to jury actions or to non-jury actions or extend it to all actions.

See generally 3 MOORE, Federat. Practice II 16 (2d ed. 1948).

2. 370 U.S. 626 (1962).

3. For the district court order of dismissal, see Link v. Wabash R.R., 291 F.2d 542, 543 (7th Cir. 1961) :

Pursuant to the inherent powers of the Court, and upon failure of plaintifi's counsel to appear at a pre-trial, which was scheduled . . . pursuant to notice, under Rule 12 [local rule], counsel having failed to give any good and sufficient reason for not appearing at said pre-trial, the cause is now dismissed. 
Shortly before the scheduled conference in the Link case, which was set pursuant to a court order issued two weeks earlier, plaintiff's attorney telephoned the judge's chambers to ask for a short postponement on the ground that he was busily filing papers with another court. ${ }^{4}$ Although the attorney had no indication that the district court would reject his request or find his explanation unsatisfactory, a dismissal order was entered that same afternoon when the attorney failed to appear. ${ }^{5}$ A new suit was effectively barred, if not by prejudice attaching to the dismissal, then by the statute of limitations. ${ }^{\circ}$ Both the Seventh Circuit and the Supreme Court held that the district court's sua sponte dismissal of a party's cause of action for his attorney's nonappearance was within the discretion of the lower court. ${ }^{7}$ However, the two courts characterized the case differently. The court of appeals assumed that the sanction was imposed for the attorney's failure to appear as ordered, ${ }^{8}$ while the Supreme Court held that the dismissal was because of a want of prosecution by the plaintift, as evi. denced in part by the attorney's failure to attend, and by the protracted history of the litigation. ${ }^{9}$ Reliance upon a want of prosecution theory in this case scems dubious, since much of the delay prior to the scheduled conference was caused by the defendant as well as the plaintiff. ${ }^{10} \mathrm{By}$ basing its affirmance of the clismissal order on want of prosecution, for which dismissal seems an appropriate sanction, the Supreme Court avoided deciding the more difficult question of whether dismissal would also be an appropriate sanction where a failure to comply with a court order to attend a conference was the only ground of dismissal. ${ }^{11}$

4. Id. at $544-45$.

5. Id. at 544 .

6. Link v. Wabash R.R., 370 U.S. 626,637 n.1 (1962). Since the effect of the dismissal was to deprive plaintiff of his potentially valuable negligence claim against defendant railroad, the absence of notice as to the possibility of dismissal and the failure to hold an adt versary hearing raised the question of the constitutional propricty of the court's action. Id. at $632-33$.

7. 291 F.2d at $546 ; 370$ U.S. at 633.

8. 291 F.2d at 545-46. Counsel for the defendant made no effort in the Court of Appeals to rely upon a want of prosecution theory as a ground for the involuntary dismissal. The only references to "want of prosecution" in the Seventh Circuit's opinion are parenthetical, describing the holding of the court in another case, and Rule 41(b), indicating the availability of the dismissal power under that circumstance. The Court of Appeals made no attempt, however, to rest its affirmance of the district court's decision on that case nor on Rule 41(b).

9. [W] are unable to say that the District Court's dismissal of this action for failure to prosecute, as evidenced only partly by the failure of petitioner's counsel to appear at a duly scheduled pre-trial conference, amounted to an abuse of discretion.

370 U.S. at 633.

10. Although it appears, as the Supreme Court assumed, that the district judge may have considered the age of the suit, the oldest civil case on his court docket ( 6 years), in rendering his dismissal, $i d$. at 628 , the judge and the defendant appeared at least as much to blame for previous delays as plaintiff or his attorney. Not only did the judge render a judgment on the pleadings for the defendant, but the defendant also requested one of the continuances in the case while not objecting to the plaintiff's own request. See 370 U.S. at 628.

11. Id. at 634 . 
Neither the Supreme Court nor the court of appeals relied on the Federal Rules as the source of the district court's power to dismiss; rather, the dismissal was found to be based upon a court's 'inherent power to enforce its rules, orders, or procedures, and to impose appropriate sanctions for failure to comply."12 However, the Court noted that Rule 41(b)-which, upon motion of a defendant, authorizes a dismissal for "failure of the plaintiff to prosecute or to comply with these rules or any order of court"13 - supports the district court's dismissal for failure to prosecute. But the Court refused to hold the Rule applicable because the defendant had not moved for dismissal below. ${ }^{14}$ The refusal to apply Rule 41(b) on this ground seems questionable, since the absence of defendant's motion in the court below seems a mere formality which should itself not bar application of the Rule. Indeed it has been held that Rule 41(b) applies in the absence of a defendant's motion. ${ }^{15}$ In characterizing the dismissal as one for a want of prosecution and in refusing to rely upon Rule 41(b), the Court apparently wanted to avoid holding that the failure of a party's counsel to attend a scheduled pre-trial conference itself should result in a dismissal of a plaintiff's cause of action under Rule 41 (b), which is the only sanction available under this rule.

Although the absence of a defendant's motion under Rule 41 (b) is not a convincing reason why the Rule should not be found to apply to situations where the plaintiff's attorney fails to attend the pre-trial conference, there are persuasive reasons supporting its inapplicability. Since the direction to the attorney to appear is an "order of court" with which the attorney and presumably the plaintiff has failed to comply, ${ }^{16}$ a literal reading of Rule 41 (b) supports the conclusion that it does apply and thus warrants the sanction of dismissal. But the application of the failure to comply with orders of the court provision of Rule 41 (b) has been limited, perhaps because the rule only provides for the sanction of dismissal of plaintiff's complaint. ${ }^{17}$ Thus, generally, its use has been

12. $291 \mathrm{~F} .2 \mathrm{~d}$ at $545 ; 370$ U.S. at 630 . That courts have such power is not open to question. Traditionally, courts have utilized this inherent power at various stages of litigation to prevent abuses and injustices, thereby assuring the proper administration and control of the judicial process. See 1 Mloore, Federar Practice [ 0.60[6] (2d ed. 1948).

13. FED. R. CIv. P. 41(b) : Involuntary Dismissal: Effect Thercof.

For failure of the plaintiff to prosecute or to comply with these rules or any order of court, a defendant may move for dismissal of an action or of any claim against him. ... Unless the court in its order for dismissal othervise specifies, a dismissal under this subdivision and any dismissal not provided for in this rule, other than a dismissal for lack of jurisdiction or for improper venue, operates as an adjudieation upon the merits.

14. 370 U.S. at 629 .

15. See cases cited in 5 Moore, Federal Practice $\llbracket 41.11$ (2), at $1036 \mathrm{n} .8$ (2d ed. 1948).

16. $291 \mathrm{~F} .2 \mathrm{~d}$ at 545 .

17. Since Rule 41(b) is located in the Trials section of the Federal Rules, its appliesbility for noncompliance with court orders issued at pre-trial has been questioned. The Supreme Court said in Societé Internationale v. Rogers, 357 U.S. 197, 207 (1958):

In our opinion, whether a court has power to dismiss a complaint because of non-compliance with a production order depends exclusively upon Rule $37 . .$. There 
restricted to instances where a dismissal is explicitly authorized under other provisions of the Federal Rules. ${ }^{18}$ For example, Rule 41(b) has been relied upon in dismissing an action for a failure to comply with a court order requiring greater specificity in the pleadings. ${ }^{10}$ For failure to comply with such at1 order, Rule 12(e) explicitly provides for the striking of the pleadings to which the motion was directed. ${ }^{20}$ Moreover, Rule 41 (b) has been used to dismiss where a party refused to comply with a court order requiring the payment of costs of a previously dismissed action based upon the same claim. ${ }^{21} \mathrm{~A}$ dismissal in these circumstances is also authorized by the Rules..$^{22}$ Rule 41 (b) has also been used to dismiss an action for failure to attend a pre-trial conference, but in this case there was also a want of prosecution, which ground, if proven, clearly justifies a dismissal..$^{23}$ In fact, the bulk of cases in which Rule 41 (b) has been relied upon are situations where the plaintiff or his attorney has engaged in dilatory tactics, constituting a failure to prosecute. ${ }^{24}$ Thus, the situations to which Rule 41(b) has been applied do not indicate that the Rule warrants dis* missal where a court order issued pursuant to Rule 16 requiring attendance at a scheduled conference has been disobeyed, since Rule 16 does not explicitly authorize dismissal or a stay of the action for noncompliance with an order of

is no need to resort to $41(\mathrm{~b})$, which appears in that part of the Rules concerned with trials and which lacks such specific references to discovery.

See also Russo v. Sofia Bros., 2 F.R.D. 80 (S.D.N.Y. 1941) (Rule 41(b) primarily controls the action at or after trial and does not apply to a dismissal of the complaint for insufficient pleading).

18. E.g., First Iowa Hydro-Elec. Coop. v. Iowa-Illinois Gas \& Elcc. Co., 245 F.2d 613 (8th Cir.), cert. denied, 355 U.S. 871 (1957); Blake v. DeVilbiss, 118 F.2d 346 (6th Cir. 1941) ; Botkins v. Sorter, 29 F. Supp. 991 (W.D. La. 1939) ; Martin v. Southern Ry, 1 F.R.D. 98 (E.D. Tenn. 1939) ; cf. Carpenter v. Carpenter, 156 F.2d 857 (D.C. Cir. 1946).

19. Blake v. DeVilbiss, 118 F.2d 346 (6th Cir. 1941); Botkins v. Sorter, 29 F. Supp. 991 (W.D. La. 1939).

20. FED. R. CIv. P. 12(e) : Motion for More Definite Statement.

If a pleading to which a responsive pleading is permitted is so vague or ambiguous that a party cannot reasonably be required to frame a responsive pleading, he may move for a more definite statement before interposing his responsive pleading. The motion shall point out the defects complained of and the details desired. If the motion is granted and the order of the court is not obeyed within 10 days after notice of the order or within such other time as the court may fix, the court may strike the pleading to which the motion was directed or make such order as it decms just.

21. Martin v. Southern Ry., 1 F.R.D. 98 (E.D. Tenn. 1939).

22. FED. R. Crv. P. 41(d): Costs of Previonsly-Dismissed Action.

If a plaintiff who has once dismissed an action in any court commences an action based upon or including the same claim against the same defendant, the court may make such order for the payment of costs of the action previously dismissed as it may deem proper and may stay the proceedings in the action until the plaintiff has complied with the order.

23. Wisdom v. Texas Co., 27 F. Supp. 992 (N.D. Ala. 1939).

24. E.g., Janousek v. French, 287 F.2d 616 (8th Cir. 1961) ; Ordinance Gauge Co. v. Jacquard Knitting Mach. Co., 265 F.2d 189 (3d Cir.), cert. dcnied, 361 U.S. 829 (1959); Red Warrior Coal \& Mining Co. v. Boron, 12 F.R.D. 10 (W.D. Pa. 1951) ; Giovanctt v. Georgetown Univ. Hosp., 22 F.R.D. 493 (D.D.C. 1958) ; Lynch v. National Bondholders Corp., 2 F.R.D. 376 (E.D. Mich. 1942). 
court issued pursuant to it. Furthermore, since Rule 41 (b) is available only to a defendant, ${ }^{25}$ and since there is no counterpart of this Rule for a plaintiff, it would seem that it was not intended to apply to court orders which could be disobeyed by defendants as well as by plaintiffs. Providing for no alternative but dismissal, Rule 41(b) seems inappropriate when applied to the pre-trial conference phase; the possibility at this stage of a variety of transgressions varying in severity by both plaintiff and defendant would seem to require a broader array of sanctions. ${ }^{26}$ It might therefore be appropriate to look at the criteria governing the imposition of sanctions for noncompliance with orders of court at another pre-trial stage, discovery, in determining the propricty of applying severe sanctions for noncompliance with orders issued pursuant to Rule 16.

In contrast to the one alternative in Rule 41(b), Rule 37, which governs the imposition of sanctions at the discovery stage, enumerates a list of sanctions, varying in severity, to be imposed for a party's noncompliance with the discovery rules or with orders of court issued pursuant to them.77 With one exception, ${ }^{28}$ however, Rule 37 does not specify criteria for selecting the sanction to be imposed in any particular instance of noncompliance. Although discovery operates primarily through private accommodation between the parties outside the ambit of the court, ${ }^{29}$ generally the sanctions listed in Rule 37 cannot be imposed prior to the issuance of a court order requiring a party to answer a particular question in a deposition or an interrogtory, to produce documents or allow the inspection and copying of documents, or to submit to a physical or mental examination. ${ }^{30}$ The only situation where a sanction may be imposed

25. See note 13 supra.

26. Instances of noncompliance may include a tardy filing of pre-trial memoranda in preparation for the conference, failure to attend the conference, or attendance at the conference without adequate preparation.

27. FED. R. CIv. P. 37 .

28. FED. R. CIv. P. 37(d) : Failure of Party to Attend or Serve Ausucrs.

If a party or an officer or managing agent of a party wilfully fails to appear before the officer who is to take his deposition, after being served with a proper notice, or fails to serve answers to interrogatories submitted under Rule 33, after proper service of such interrogatories, the court on motion and notice may strike out all or any part of any pleading of that party, or dismiss the action or procceding or any part thereof, or enter a judgment by default against that party.

29. Kaufman, Judicial Control Over Discovery, 28 F.R.D. 111, 116 (1962).

30. FED. R. CIv. P. 37(b) : Failure to Comply With Order.

(1) Contempt. If a party or other witness refuses to be sworn or refuses to answer any question after being directed to do so by the court in the district in which the deposition is being taken, the refusal may be considered a contempt of that court.

(2) Other Consequences. If any party or an officer or managing agent of a party refuses to obey an order made under subdivision (a) of this rule requiring him to answer designated questions, or an order made under Rule 34 to produce any document or other thing for inspection, copying, or photographing or to permit it to be done, or to permit entry upon land or other property or an order made under Rule 35 requiring him to submit to a physical or mental examination, the court may make such orders in regard to the refusal as are just, and among others the following: 
in the absence of a court order is where a party, after proper notice by the opposing party, "wilfully" fails to appear before the officer who is to take his deposition or fails to serve answers to interrogatories. ${ }^{31}$ Section (d) of Rule 37 , which applies solely to the latter situation, is the only part of Rule 37 which provides a criterion determining the appropriateness of a particular sanction. It reserves the use of the drastic sanctions of dismissal or entry of a default judgment for occasions where a party "wilfully" fails to attend the taking of his deposition or to serve answers to interrogatories. Although the reports of the framers of the Federal Rules do not indicate the rationale for the inclusion of this criterion in Rule 37(d) and not in Rule 37(b), which enumerates sanctions available for all the other instances of noncompliance with discovery orders, its incorporation there is not inexplicable. Because of the de-emphasized role of pleadings characteristic of the Federal Rules, ${ }^{32}$ discovery was deemed essential as a means of facilitating ascertainment of the facts and disclosure of positions relied upon by the parties, thereby assisting the determination of the substantive rights of parties on the merits. ${ }^{33}$ In short, discovery was, and still is, viewed as a means to an end. Thus courts can utilize the drastic sanctions previously mentioned prior to the issuance of a court order only when noncompliance is expressed by a wilful defiance of a notice for the taking of a deposition or the serving of interrogatories, an attitude suggestive of an unwillingness to assist in any disclosure of facts or issues. Since the inexcusable conduct of the noncomplying party renders future participation and assistance in the discovery

(i) An order that the matters regarding which the questions were asked, or the character or description of the thing or land, or the contents of the paper, or the physical or mental condition of the party, or any other designated facts shall be taken to be established for the purposes of the action in accordance with the claim of the party obtaining the order;

(ii) An order refusing to allow the disobedient party to support or oppose designated claims or defenses, or prohibiting him from introducing in evidence designated documents or things or items of testimony, or, from introducing evidence of plysical or mental condition;

(iii) An order striking out pleadings or parts thereof, or staying further proceedings until the order is obeyed, or dismissing the action or proceeding or any part thereof, or rendering a judgment by default against the disobedient party;

(iv) In lieu of any of the foregoing orders or in' addition thereto, an order dirceting the arrest of any party or agent of a party for disobeying any of such orders except an order to submit to a physical or mental examination.

31. See note 28 supra.

32. See 3 Moore, Federal Practice $\llbracket 16.05$, at 1106 (2d ed. 1948); Clarl;, Simplified Pleading, 2 F.R.D. $456-58$ (1943).

33. See 4 MOORE, op. cit. supra note $32, \llbracket 26.07$, at 1078. The Supreme Court in Hickman v. Taylor, 329 U.S. 495, 500 (1947), clearly recognized the vital role of discovery: The new rules ... . restrict the pleadings to the task of general noticc-giving and invest the deposition-discovery process with a vital role in the preparation for trial. The various instruments of discovery now serve (1) as a device, along with the pretrial hearing under Rule 16, to narrow and clarify the basic issues between the parties, and (2) as a device for ascertaining the facts, or information as to the existence or whereabouts of facts, relative to those issues. Thus civil trials in the federal courts no longer need be carried on in the dark.... 
process unlikely, he is at that point denied the opportunity to have his rights determined upon the merits.

Although not incorporated in Rule 37(b), ${ }^{34}$ the courts have not limited the wilful violation criterion of Rule 37 (d) to situations where a party fails to attend the taking of his deposition or to serve answers to interrogatories, but have used it to govern the imposition of sanctions for other instances of noncompliance with discovery procedures. Thus, for instance, courts have utilized this standard when faced with noncompliance with orders for the production of documents, orders for a physical examination of a party, and orders compelling an answer to a specific question. ${ }^{35}$ Although there is no unanimity among the federal courts concerning the adoption of the standard in these latter areas, $^{36}$ in most of those cases of noncompliance where the question of wilfulness has been mentioned or litigated, courts have refused to employ the drastic sanctions of dismissal or default judgment in the absence of a finding of a wilful noncompliance. ${ }^{37}$ This attitude on the part of the courts that have incorporated the wilful violation criterion in Rule 37(b) seems to rest on the propositions

34. See note 30 supra.

35. E.g., Roth v. Paramount Pictures Distrib. Corp., 8 F.R.D. 31 (W.D. Pa. 1948); Campbell v. Johnson, 101 F. Supp. 705 (S.D.N.Y, 1951); Newcomb v. Universal Alatch Corp., 27 F. Supp. 937 (E.D.N.Y. 1939). The court, in the Roth case, in the absence of a finding of a wilful violation of its production order for certain specified books, denied, infer alia, defendants' motion to dismiss a plaintiff's complaint with prejudice. Similarly, the court, in the Campbell case, denied defendant's motion for an order to preclude the plaintiff from contradicting an affirmative defense where the evidence failed to show a wilful violation to comply with the court's production order for records which might have proved crucial to the defendant in establishing his defense. Perhaps cognizant of the fact that the use of a preclusion order might prejudice a noncomplying party's case severely, the court maintained that only in an exceptional instance is the imposition of a preclusion order justified:

Rule 37(b) ... does not by its wording require that before an order of preclusion may be made there must be a finding of wilful failure to comply with an order of discovery. It seems, however, that only in an exceptional case would such an order be justified, and that absent wilful disobedience there must be proof of gross indifference to the rights of the adverse party. ... .

101 F. Supp. at 707. See also Hinsor v. Michigan MLut. Liab. Co., 275 F.2d 537 (5th Cir. 1960) (failure to attend physical examination pursuant to court order must have been wilful to justify dismissal) ; Valenstein y. Bayonne Bolt Corp., 6 F.R.D. 363 (E.D.N.Y. 1946) (wilful disposal of bolts ordered to be produced resulted in striking of plaintiff's complaint in part); accord, Bourne, Inc. v. Romero, 23 F.R.D. 292 (E.D. La. 1959) (failure to produce documents, coupled with complete unwillingness to participate in pre-trial conference and other discovery procedure, resulted in entry of default judgment).

36. Bernat จ. Pennsylvania R.R, 14 F.R.D. 465 (E.D. Pa. 1953) (preclusion order entered in absence of a finding of wilful violation of production order); United States $v$. Cotton Valley Operators Comm'n, 9 F.R.D. 719 (W.D. La. 1949), aff'd, 339 U.S. 940 (1950) (complaint dismissed in absence of a finding of a wilful violation of production order); accord, Mooney v. Central Motor Lines, 222 F.2d 569 (6th Cir. 1955) (motion to amend dismissal with prejudice, entered in absence of mention of wilful violation of court's order to submit to a physical examination, to dismissal without prejudice denied). In the Mooney case, though the court did not call the noncomplying party's conduct wilful, it might be deemed such.

37. See notes 35-36 stpra. A holding in contempt presupposes a wilful act. 
that discovery is but a way-station in the conduct of litigation, and that the imposition of a drastic sanction for non-wilful violations would be to thwart the underlying purpose of the Rules $:^{38}$ the determination of the substantive rights of parties on the merits.

Many federal courts, cognizant of this latter consideration, are solicitous and tolerant of less than wilful transgressions, such as the neglectful failure of a party to attend a deposition hearing or to furnish specified documents. ${ }^{30}$ Rather than employ a drastic sanction, such as the entry of a default judgment or a dismissal of a complaint, these courts have preferred to rely on conditional orders providing for dismissal or judgment only if the noncompliance continues. ${ }^{40}$ And where the failure of a party to answer an interrogatory or attend a deposition hearing is caused by neglect on the part of his attorney, some courts have treated such noncompliance as non-wilful and thus not warranting the ultimate sanction of dismissal. ${ }^{41}$ In these circumstances courts have also used a conditional dismissal order. And even a wilful noncompliance has been thought to merit a reprieve in the form of a conditional order, ${ }^{42}$ a disposition exemplifying the more lenient treatment of noncompliance at this stage of the proceedings.

38. Holtzoff, Origins and Sources of the Federal Rules of Civil Procedure, 30 N.Y. U.L. REv. 1057, 1059 (1955) :

The underlying philosophy of the new procedure may be said to consist of two distirct strands. The first is a shift of emphasis from rigid adherence to a prescribed procedure to a distinct effort to bring about the disposition of every case on the merits without regard to compliance with detailed requirements of adjective law and overlooking any discrepancy or error that does not actually affect the substantive rights of the parties....

39. See, e.g., Maresco v. Lambert, 2 F.R.D. 163 (E.D.N.Y. 1941); Haskell v. Philadelphia Transp. Co., 19 F.R.D. 356 (E.D. Pa. 1956). Where neglectful disregard of a notice to attend a deposition hearing by plaintiff's attorney resulted in plaintiff's failure to attend, the court, in the Maresco case, denied defendant's motion to dismiss on condition that plaintiff pay costs of opposing party's counsel fees arising from the inconvenience suffered.

40. E.g., Terry Carpenter, Ltd. v. Ideal Cement Co., 117 F. Supp. 441 (D. Neb. 1954); Pierre v. Bernuth, Lembcke Co., 21 F.R.D. 194 (S.D.N.Y. 1957); Socha v. Webber, 11 F.R.D. 124 (D. Alaska 1951) ; Dann v. Compagnie Generale Trans-Atlantique, Ltd., 29 F. Supp. 330 (E.D.N.Y. 1939) ; cf. Millinocket Theatre, Inc. v. Kurson, 35 F. Supp. 754 (D. Me. 1940).

41. E.g., United Sheeplined Clothing Co. v. Arctic Fur Cap Corp., 165 F. Supp. 193 (S.D.N.Y. 1958) (where defendant's failure to attend a deposition hearing was due to his attorney's neglect, court denied plaintiff's motion for default judgment on condition that defendant's attorney pay resulting costs to plaintiff, including reasonable attorncy fces); Dunn v. Pennsylvania R.R., 96 F. Supp. 597 (N.D. Ohio 1951) (conditional order of dismissal entered, in action removed from state court, where failure of plaintiff to answer interrogatories was due to his attorney's ignorance of practice in federal courts); Marcsco v. Lambert, 2 F.R.D. 163 (E.D.N.Y. 1941); cf. Millinocket Theatre, Inc. v. Kurson, 35 F. Supp. 754 (D. Me. 1940). But cf. Alevizopoulos v. Central Am. Agency, Inc., 21 Fed. RULES SERV. 37b.243 (S.D.N.Y. Aug. 18, 1955). In addition to the use of conditional orders where noncompliance is caused by the actions of the attorney, courts have directed sanctions at the lawyer rather than at the unoffending client. See, e.g., Allen v. United States, 16 FED, RuLES SERY, 37b.21, case 1 (E.D. Pa. May. 21, 1951). See also note 54 infra. 
It might be argued that the wilful violation standard and the conditional order dispositions utilized at discovery have no application to the pre-trial conference stage. Since discovery operates principally outside the ambit of the court, ${ }^{43}$ with the judge engaged only in a supervisory role, ${ }^{14}$ the effects of noncompliance with the discovery rules, as, for example, a notice to appear at a deposition hearing, are the opposing party's inconvenience, the possibility of attendant counsel fees, and the additional expense of filing a motion with the court for an order compelling compliance with the desired mode of discovery procedure. On the other hand, since the pre-trial conference takes place under the close and active supervision of the judge, ${ }^{45}$ noncompliance with an order to attend the conference has a far more serious consequence. In addition to the inconvenience suffered by the opposing party and the additional counsel fees necessary to obtain a court order, noncompliance at this phase disrupts the calendar of the court. Since other conferences might have been scheduled for that time, noncompliance with the court order thus results in a significant social cost, especially in light of the present congestion of court dockets. ${ }^{40}$ Furthermore, while discovery operates in a protracted setting, frequently involving the employment of discovery devices over a considerable length of time, the pretrial conference ordinarily occupies a much briefer time span, generally less than a day. But to rely on these distinctions as dispositive of the possible applicability of the sanctional guidelines employed at discovery is to focus on the fact that the court's closer involvement in the pre-trial conference phase varrants a more severe treatment of noncompliance without considering the fundamental similarities between the two pre-trial stages.

Both proceedings are designed to expedite litigation through the clarification and simplification of issues and to assist in the possible disposition of a case short of trial. ${ }^{47}$ Discovery enables a party to learn the basis of the positions

42. Saltzman v. Birrell, 156 F. Supp. 538, 540 (S.D.N.Y. 1957).

43. See note 29 sipra.

44. FED. R. CIV. P. 30(b) \& (d).

45. See 3 Moore, Federal Practice $\int 16.11$ (2d ed. 1948).

46. Olney, An Analysis of the Docket Congestion in the U.S. District Courts in the Light of the Enactment of the Ommibus Judgeship Bill, 29 F.R.D. 217 (1962).

Against this backdrop of overcrowded dockets, noncompliance with a court order by failure to attend a scheduled conference becomes equated with delay. See In re 1203, Inc, 3 Fed. Rules Serv. 2d. 16.43, case 1 (E.D. Pa. Oct. 19, 1960). And the effect of such failure is to destroy the usefulness of the pre-trial conference as a device to promote the expedition of litigation, thereby reducing the docket congestion. Recognizing this administrative burden, courts could consider severe treatment of noncompliance with an order to attend a conference at this stage of pre-trial a justifiable response to the needs of the system. Thus, a district court in Pennsylvania, in deciding to refer the entire action to a referce in bankruptcy, held that the bankrupt's failure to appear at a pre-trial conference or to offer any reasonable excuse for its absence constituted a waiver of its right to jury trial, and said:

If pre-trial conferences are to be of any benefit in aiding the court to dispose of its business, they must be treated seriously. Neither counsel nor their clients may be permitted to trifle with the court and thus string out cases that should be disposed of promptly. In no other way can we clean up our bachlog of cases.

Id. at 291.

47. See note 45 supra. 
maintained by his adversary ; and, by disclosing the substantial points of dispute between the parties, serves to clarify the basic issues of the case. ${ }^{48}$ Similarly, the pre-trial conference promotes the narrowing of issues by providing at conciliatory atmosphere in which the parties, under the supervision and direction of a judge, are able to apprise themselves more fully of the basic issues at hatud and to eliminate their insignificant points of disagreement. ${ }^{40}$ Again, just as the use of discovery, by providing materials outside of the pleadings on which to support a claim or defense, enables a court to render a summary judgment and thereby dispose of a case short of trial, ${ }^{50}$ so the conference, by promoting voluntary settlements, serves this end. ${ }^{51}$ Further, both discovery and the pre-trial conference operate in a procedural system designed to eliminate the plethora of technical motions and victories based on technical errors existing under the earlier practice. ${ }^{52}$ Yet if transgressions at pre-trial stages can lead to the imposition of a drastic sanction at each instance of noncompliance, the advantages of the system can become lost in a barrage of cross-motions for dismissal following each technical error in the hope of an easy victory without reaching the merits.

These similarities between the two pre-trial procedures suggest that the use of the wilful violation criterion and conditional orders, less harsh in their impact upon the party than immediate dismissal, might be more appropriate methods to deal with noncompliance with court orders at the pre-trial conference. The importation of such a standard would indicate recognition of the fact that to penalize litigants too severely for each instance of noncompliance is to place too high a premium on the conference as an end in itself. In addition to recognizing that the pre-trial conference is primarily designed to facilitate the trial, not to prevent it, adoption of this criterion would afford due weight to the concept of "fairness" implicit in the requirement that there be a wilful or contumacious act before the drastic sanctions of dismissal or default judgment are employed. Moreover, the use of a conditional order of dismissal, stating that the order will become final unless the noncomplying party fulfills the re-

48. See 3 Moore, Federal Practice $\llbracket 16.05$ (2d ed. 1948).

49. For a discussion of the court's role in simplifying issues at the pre-trial conference, see Note, The Role of the Court in Simplifying the Triable Issues at the Pre-Trial Conference, 72 YALE L.J. 383 (1962). A method often used by attorneys to eliminate their minor points of disagreement is to stipulate them out of the case entirely.

50. See FEd. R. Crv. P. 56(c) \& (d).

51. See 3 Moore, op. cit. supra note $48, \Uparrow 16.17$, at 1123 :

$[O]$ ne of the most valuable functions of the pre-trial conference is, or can be, the promotion of voluntary settlements.

Moreover, the narrowing of issues expedites the litigation process by reducing the amount of time needed at trial for consideration of a case.

52. See note 38 sulpra. Furthermore, the pre-trial conference can also be viewed as operating in a rather protracted setting. The necessary preparation for the conference itself, involving the early filing with the court of pre-trial memoranda on the issues and facts in dispute; the entry of a pre-trial order specifying the results reached in the conference; and the use of a number of conferences, a predominant practice in the "big" cases, all contribute to protraction of the pre-trial conference phase. 
quirements of the court order within a stated period of time, such as attendance at the conference, seems an efficacious alternative disposition. Since the time limitation in the order may be quite short, delay resulting from the postponement of the conference would be minimal. As a basis for the use of a drastic sanction at the pre-trial conference phase-one which eliminates the noncomplying party's opportunity to wage a trial on the merits-the wilful violation standard, ${ }^{53}$ if adopted by the courts, would tend to inhibit the district court's employment of the dismissal sanction without a closer examination of its appropriateness under the particular circumstances of a case. Fear of reversal on appeal unless the severe sanction was clearly warranted under the criterion would temper the lower court's discretion at this stage of the proceedings.

It may be contended, nevertheless, that the use of the wilful violation standard and the conditional order would be inadequate weapons to treat noncompliance at the pre-trial conference phase. Neither device, it could be argued, would serve as an adequate deterrent against non-wilful disregard of court orders. If parties knew that they would have a second chance to comply so long as they were not wilfully flouting the court's order, these measures would not promote the desired due diligence in compliance. Where the end sought is attendance at the conference, nonattendance, even if non-wilful, would still result in disruption of the court's calendar and perhaps a loss of the judge's services during the time the conference was originally scheduled. But an alternative disposition which will not prejudice a party's right to a trial on the merits is available to promote compliance in the first instance. For a court may utilize disciplinary actions against the party's attorney where the attorney is primarily responsible for the noncompliance. ${ }^{54}$ Sanctions directed at a party's attorney have been used, albeit infrequently, for noncompliance with orders of court at discovery and the pre-trial conference stages, especially where the party did not know and could not be expected to know that his attorney would prove derelict in his duties. $^{55}$ In these cases, courts have been willing to disregard the lawyer-client agency principle which provides that ordinarily parties are bound by the actions

53. See note 28 supra.

54. E.g., United Sheeplined Clothing Co. v. Arctic Fur Cap Corp., 165 F. Supp. 193 (S.D.N.Y. 1958) (expenses charged against the attorney); Osolin v. S.S. Colorado, 1 FED. Rules SERv. 2d 37a.22, case 1 (N.D. Cal. July 7, 1958) (reasonable expenses and counsel fees were charged against the attorney); Austin Theatre, Inc. v. Warner Bros. Pictures, Inc., 22 F.R.D. 302 (S.D.N.Y. 1958) (cost incurred by defendants' attorneys in securing order to compel compliance were charged against plaintiff's attorney); Allen v. United States, 16 Fed. Rules Serv. 37.21, case 1 (E.D. Pa. May 21, 1951) (expenses charged against the attorney). See also note 41 supra.

55. See notes 41 and 54 supra. Courts have not only wielded sanctions against the crring attorney to prevent the visiting of the attorney's sins upon the unoffending client, but where they have not directed a sanction against the lawyer, although he was at fault, they sometimes treat the party more leniently, as evidenced by the use of a conditional order of dismissal. Maresco v. Lambert, 2 F.R.D. 163 (E.D.N.Y. 1941); Dunn v. Pennsylvaniz R.R., 96 F. Supp. 597 (N.D. Ohio 1951). See also, Rosenberg, Sanctions to Effectuate Pretrial Discovery, 58 Cotuns. L. Rev. 480, 491 (1958). 
of their attorney. ${ }^{56}$ Thus where a party's failure to comply with an order calling for the answering of interrogatories was due entirely to his attorney's disregard of the court order, a court charged the expenses incurred by the oppos* ing party in obtaining an order compelling compliance and counsel fees against the erring attorney. ${ }^{57}$ And in Gamble v. Pope \& Talbot, Inc., ${ }^{\text {b8 }}$ where a party's failure to comply with a local court rule requiring the timely filing of a pre-trial memorandum was caused by his attorney's inadvertence, a fine was levied by the lower court against the neglectful attorney. Although the Third Circuit reversed, ${ }^{59}$ holding that a court has no power to fine an attorney who was neither held in contempt nor given a hearing, the lower court's reasoning retains its vitality: where the attorney is clearly at fault, the unoffending party should not suffer. Moreover, since the Supreme Court has not passed on the constitutional propriety of a fine in such circumstances, ${ }^{60}$ this measure is still available in other circuits. In addition, alternative modes of discipline against the attorney might include: (1) a reprimand by the court, (2) a finding of contempt, or (3) a prohibition against practicing for a limited time before the court whose order was neglected or disregarded. It seems fairly clear that the judicious use of such measures would tend to promote attorney compliance in the first instance.

56. For an expression of the lawyer-client agency principle, see Link v. Wabash $R, R_{\text {, }}$ 370 U.S. 626, 634 (1962) : "Each party is deemed bound by the acts of his lawyer-agent and is considered to have 'notice of all facts, notice of which can be charged upont the attorney." "

57. Allen v. United States, 16 Fed. Rules Serv. 37b.21, case 1 (E.D. Pa. May 21, 1951). The court said:

Of course, the party is answerable for what his attorneys do or fail to do in the conduct of a suit, but in the present case it is undisputed that the respondent itself is not actually to blame for the default, but that it was entirely due to the respondent's attorney's disregard of the court's order.

Id. at 507.

58. Gamble v. Pope \& Taibot, Inc., 191 F. Supp. 763 (E.D. Pa. 1961).

59. Gamble v. Pope \& Talbot, Inc., 307 F.2d 729 (3d Cir. 1962), modifying 191 F. Supp. 763 (E.D. Pa. 1961), review denied stb nom. United States District Court for Eastern Pa. v. Mahoney, 31 U.S.L. WeEK 3152 (3d Cir. Nov. 6, 1962). The Court of Appeals in the Gamble case, after indicating that "to impose such a penalty for conduct not found to bo contemptuous and without the procedural safeguards given by Rule 42 of the Federal Rules of Criminal Procedure violates the Fifth Amendment," 307 F.2d at 731, said:

Absent authority, the district court's power to penalize appellant (the attorney) is limited by contempt statute, 18 U.S.C.A. $\$ 401$, and by Rule 42 of the Federal Rules of Criminal Procedure. Section 401 permits the district court to impose fines only for specified conduct enumerated therein. If the conduct does not fall within the statute, it has no such power....

Id. at 732. Thus, as the opinion indicates, a fine can still be levied in the Third Circuit against a noncomplying attorney; however, procedural safeguards-notice and a hearingmust be provided for, and the conduct must fall within the terms of the statute in order for the imposition of a fine to be upheld.

60. The Supreme Court denied review in the Gamble case on November 6, 1961, sub nonn. United States District Court for Eastern Pa. v. Mahoney, 31 U.S.L. WEER 3152 (3d Cir. Nov. 6, 1962). 
The following hypotheticals illustrate the application of the wilful violation criterion and the suggested alternative sanctions that might be employed. (1) Assume that an attorney receives notice a few weeks before a scheduled pretrial conference of an order to attend the pre-trial conference. Shortly thereafter, he misplaces the notice and consequently fails to attend the conference. Under these circumstances, the noncompliance might be deemed to be nonwilful. Accordingly, the court could employ a conditional order of dismissal, and, at the same time, either reprimand the attorney or direct him to pay the opposing party's counsel fees. Where a conditional order of dismissal is issued, both the attorney and the client would be deemed to be fully apprised of the consequences of any subsequent noncompliance. Where a failure to comply followed, the court could then allow its drastic sanction to operate: the conditional order would become final. (2) Assume that an attorney receives notice of a scheduled conference, and without notifying his client, attends to other legal business in another city on the day of the conference, thereby failing to attend the scheduled conference. Though it might be said that the attorney is wilfully flouting the court's order here, the lack of knowledge on the part of the client of his attorney's misconduct should prevent the operation of the vilful violation criterion under these circumstances. Reserving the use of the drastic sanction of immediate dismissal, the court might employ the conditional dismissal, and, at the same time, wield a more stringent sanction against the wilful attorney, such as the imposition of the opposing party's counsel fees and a fine. (3) Assume that an attorney receives notice of an order to attend a scheduled conference, and notifies his client of the scheduled conference. Then on the day of the conference the attorney and the client decide to play a game of golf at the latter's country club. Under these circumstances, the wilful violation would be established, and the court could appropriately employ an immediate dismissal while levying a sanction against the attorney at the same time. Thus, in response to the initial contention concerning the ineffectiveness of the alternative dispositions available, it appears that the utilization of these three devicesthe wilful violation criterion, the conditional order of dismissal, and disciplinary actions against an attorney-would serve as sufficient deterrents against noncompliance with a court order at the pre-trial conference phase. Furthermore, the employment of these devices, while fully heeding administrative concerns, fulfills the central purpose of the Federal Rules-to provide a fair procedure for the determination on the merits of rights of the parties. ${ }^{01}$

61. This latter contention was endorsed by the Second Circuit in Bardin v. MIondon, $298 \mathrm{~F} .2 \mathrm{~d} 235$ (2d Cir. 1961). Following the refusal of plaintiff's counsel to proceed at trial or its scheduled date, the district court dismissed plaintiff's complaint with prejudice on grounds of want of prosecution. On appeal, the Second Circuit, holding that the lower court did not abuse its discretion, remanded the case with instructions that the action be dismissed without prejudice on condition that plaintiff's counsel pay all of the trial and appellate costs taxed to the plaintiff and $\$ 100$ in addition. Id. at 238. Acknowiedging the tremendous calendar problems faced by the Southern District of New York, the appellate court, nevertheless, did not approve the harsh sanction directed at the plaintiff by the lower court. 
As the Link case demonstrates, the law on the use of sanctions at the pretrial conference phase is developing without the establishment of clearly defined standards. Rule 16 provides no assistance here; it neither mentions which sanctions are available to the court nor furnishes any guidelines for their employment. Moreover, reliance upon Rule 41 (b) or resort to the concept of a court's inherent power does not help a court to choose among the various sanctions available. The $\operatorname{Link}$ case-highlighted by the drastic nature of the sanction, and the direction of the sanction at an unknowing party who should not be deemed responsible for the misconduct of his attorney-illustrates the need for judicial thought on the subject of standards to govern the use of sanctions at the pretrial conference phase. The body of law in the discovery area provides a starting point for the development of standards governing the use of sanctions for noncompliance with orders of court issued pursuant to Rule 16. 